\title{
FAKTOR PENGHAMBAT PENYUSUNAN SILABUS DAN RPP KURIKULUM 2013 BAGI GURU BIOLOGI DI SMP KECAMATAN BUMAL KABUPATEN MAMASA
}

\author{
${ }^{1}$ B Bambang Supriadi, ${ }^{2}$ Muh. Yahya, ${ }^{3}$ Surahman Nur \\ ${ }^{1}$ Mahasiswa Biologi STKIP-PI, Makassar, Indonesia \\ ${ }^{2}$ pendidikan Ekonomi STKIP-PI, Makassar, Indonesia \\ ${ }^{3}$ Pendidikan Biologi STKIP-PI, Makassar, Indonesia
}

*Email Korespondensi: surahmannur1007@gmail.com

\section{INFO ARTIKEL}

Diterima 21 Juli 2021

Dipublikasikan 31 Juli 2021

\begin{abstract}
A B STRAK
Penelitian ini bertujuan untuk mengetahui dan menjelaskan faktor penghambat yang dihadapi guru biologi dalam menyusun silabus dan Rancangan Pelaksanaan Pembelajaran (RPP) Kurikulum 2013 (K13) di SMP se Kecamatan Bumal Kabupaten Mamasa. Jenis penelitian ini adalah deskriptif kualitatif. Subjek pada penelitian ini adalah semua guru mata pelajaran biologi yang ada di SMP se-Kecamatan Bumal Kabupaten Mamasa. Teknik pengumpulan data dilakukan menggunakan angket. Hasil penelitian menunjukkan bahwa: terdapat beberapa faktor penghambat yang dihadapi guru biologi dalam menyusun silabus dan RPP Kurikulum 2013 di SMP seKecamatan Bumal Kabupaten Mamasa, yaitu: kurangnya pelatihan Kurikulum 2013 bagi tenaga pengajar di daerah terpencil, guru di sekolah sangat kekurangan fasilitas penunjang pembelajaran seperti buku-buku paket berbasis K13, guru kekurangan alat-alat untuk praktek seperti torso dan fasilitas laboratorium biologi, di sekolah tidak ada komputer dan listrik, guru tidak dapat mengakses silabus dan RPP secara online karena di desa belum ada jaringan internet, kemampuan dasar yang dimiliki siswa masih terbatas, keadaan sekolah dan tenaga pengajar serta peserta didik yang serba kekurangan. Kesimpulan: banyaknya faktor penghambat internal dan eksternal menjadi kendala guru dalam penyusunan dan pengembangan silabus dan RPP K13 di SMP se Kecamatan Bumal Kabupaten Mamasa.
\end{abstract}

Kata Kunci: Faktor Penghambat, Silabus, RPP K13, Guru Biologi

\section{INHIBITING FACTOR FOR THE DEVELOPMENT OF THE 2013 SYLLABUS AND RPP CURRICULUM FOR BIOLOGY TEACHERS IN JUNIOR HIGH SCHOOL DISTRICT BUMAL, MAMASA REGENCY}

\begin{abstract}
This study aims to identify and explain the inhibiting factors faced by biology teachers in compiling the syllabus and the 2013 Curriculum Implementation Plan (RPP) in junior high schools throughout Bumal District, Mamasa Regency. This type of research is descriptive qualitative. The subjects in this study were all biology subject teachers in junior high schools throughout the Bumal District, Mamasa Regency. Data collection techniques were carried out using a questionnaire. The results showed that: there were several inhibiting factors faced by biology teachers in compiling the 2013 curriculum syllabus and lesson plans in junior high schools throughout the Bumal sub-district, Mamasa district, namely: lack of 2013 curriculum training for teaching staff in remote areas, teachers in schools lacking learning support facilities such as textbooks based on $\mathrm{K} 13$, teachers lack tools for practice such as torsos and biology laboratory facilities, in schools there are no computers and electricity, teachers cannot access syllabus and lesson plans online because in the village there is no internet network, basic skills possessed The number of students is still limited, the state of the school and teaching staff and students are lacking. Conclusion: the many internal and external inhibiting
\end{abstract}


factors are the obstacles for teachers in the preparation and development of the K13 syllabus and lesson plans in junior high schools in Bumal District, Mamasa Regency.

Keywords: Inhibiting factor, Syllabus, RPP K13, Biology teachers

\section{Pendahuluan}

Pendidikan adalah usaha sadar dan terencana untuk mewujudkan suasana pembelajaran agar peserta didik secara aktif mengembangkan potensi dirinya untuk mengembangkan kekuatan spiritual keagamaan, pengendalian diri, kepribadian, kecerdasan, akhlak mulia, serta keterampilan yang diperlukan dirinya dan masyarakat. Pendidikan meliputi guru keahlian khusus, dan juga sesuatu yang tidak dapat dilihat tetapi lebih mendalam yaitu pemberian pengetahuan, pertimbangan dan kebijaksanaan (Prasetya, 2015).

Perkembangan dan kemajuan pendidikan harus disesuaikan dengan perkembangan ilmu pengetahuan dan keadaan lingkungan yang ada. Saat ini pemerintah telah melakukan berbagai upaya untuk merenovasi sistem pendidikan di Indonesia, salah satunya dengan perbaikan kurikulum. Undang-Undang Nomor 20 (2003) tentang Sistem Pendidikan Nasional Pasal 1 Butir 19, kurikulum adalah seperangkat rencana dan pengaturan mengenai tujuan, isi, dan bahan pelajaran serta cara yang digunakan sebagai pedoman penyelenggaraan kegiatan pembelajaran untuk mencapai tujuan pendidikan tertentu. Sejak jaman kemerdekaan sampai sekarang, kurikulum di Indonesia telah mengalami banyak perubahan. Mulai dari kurikulum 1947 sampai kurikulum terbaru yang belum lama diterapkan saat ini yaitu Kurikulum 2013 (Asmarani, 2018).

Kurikulum pertama disusun pada tahun 1950, selanjutnya pada tahun 1958 dibuat lagi kurikulum yang dikenal dengan kurikulum tahun 1958. Dibuat kurikulum pada tahun 1964 yang dilaksanakan pada tahun 1965. Tahun 1968 dibuat kurikulum yang meliputi pembinaan moral, budi pekerti, agama, kecerdasan dan keterampilan serta fisik. Kurikulum 1975 bertumpu pada pengembangan aspek kognitif, afektif dan psikomotorik. Kurikulum 1984 sebagai penyempurnaan kurikulum-kurikulum sebelumnya menekankan pada Cara Belajar Siswa Aktif (CBSA). Selama 10 tahun CBSA berjalan dan akhirnya dibuat lagi kurikulum baru pada tahun 1994 yang juga dimaksudkan untuk penyempurnaan kurikulum sebelumnya. Tahun 2004 dibuat Kurikulum Berbasis Kompetensi atau lebih dikenal dengan nama KBK yang dimaksudkan untuk penyempurna kurikulum sebelumnya. Selanjutnya, pada tahun 2006 kurikulum tersebut diubah lagi menjadi Kurikulum Tingkat Satuan Pendidikan (KTSP) yang dimaksudkan sebagai penyempurnaan kurikulum sebelumnya (Nur, 2010).

Kurikulum yang ditetapkan sekarang adalah Kurikulum 2013 (K13) yang merupakan penyempurnaan dari Kurikulum Tingkat Satuan Pendidikan (KTSP). Kurikulum 2013 merupakan kurikulum yang mengutamakan pada pemahaman, skill dan pendidikan karakter, di mana siswa dituntut untuk paham atas materi, aktif dalam proses berdiskusi dan presentasi serta memiliki sopan santun dan disiplin yang tinggi. Kurikulum ini memiliki tiga aspek penilaian, yaitu aspek pengetahuan, aspek keterampilan dan aspek sikap dan perilaku (Prasetya, 2015)

Perubahan kurikulum ini harus diantisipasi dan dipahami oleh berbagai pihak, terutama oleh pendidik. Hambatan utama dalam pengembangan kurikulum di sekolah terletak pada pendidik, diantaranya karena kurangnya pengetahuan dan kemampuan pendidik itu sendiri. Salah satu kesulitan yang di hadapi pendidik atau guru di sekolah-sekolah adalah hambatan dalam menyusun silabus dan Rancangan Pelaksanaan Pembelajaran (RPP) Kurikulum 2013 (Asmarani, 2018).

Kecamatan Bumal yang berada di Kabupaten Mamasa merupakan kawasan pedesaan terpencil. Beberapa SMP yang berada di kecamatan ini seperti SMP Negeri 01 Buntumalangka, SMP Swasta Puncak Sumua, SMP Swasta Tallusikambik, SMP Swasta Ranteberang, dan SMP Negeri 3 Buntumalangka, masih memiliki tenaga pendidik yang hanya tamatan SMA sehingga pengetahuan dan kemampuan pendidik dalam pembuatan Silabus dan RPP K13 masih sangat kurang. Selain masalah pendidik, penyaluran buku kurikulum 2013 juga belum maksimal ke sekolah-sekolah tersebut sehingga di beberapa sekolah masih menggunakan buku-buku berbasis KTSP. Hal ini dikarenakan akses jalan yang sulit. Selain itu, silabus yang biasanya dapat 
disalurkan melalui website dan dapat langsung diunduh, tidak dapat dilakukan di kecamatan Bumal karena belum adanya jaringan internet. Tenaga pendidik di sekolah-sekolah kecamatan Bumal juga banyak yang belum mampu mengoperasikan komputer dan belum paham cara mengakses internet. Berdasarkan uraian inilah, maka penulis tertarik untuk meneliti faktor penghambat penyusunan silabus dan RPP Kurikulum 2013 bagi guru Biologi di SMP se-kecamatan Bumal.

\section{Metode Penelitian}

\subsection{Tempat Penelitian}

Penelitian ini dilaksanakan di SMP se Kecamatan Bumal Kabupaten Mamasa yang terdiri dari 5 sekolah yaitu SMP Negeri 01 Buntumalangka, SMP Swasta Puncak Sumua, SMP Swasta Tallusikambik, SMP Swasta Ranteberang, dan SMP Negeri 3 Buntumalangka.

\subsection{Jenis Penelitian}

Jenis penelitian ini adalah penelitian deskriptif kualitatif, yaitu bertujuan untuk mengetahui dan menjelaskan tentang faktor penghambat yang dihadapi guru biologi dalam menyusun silabus dan rancangan pelaksanaan pembelajaran (RPP) Kurikulum 2013 (K13) di SMP se Kecamatan Bumal Kabupaten Mamasa.

2.3 Variabel Penelitian

Variabel penelitian ini yaitu faktor penghambat yang dihadapi guru biologi dalam menyusun silabus dan rancangan pelaksanaan pembelajaran (RPP) dan Kurikulum 2013 (K13) di SMP se Kecamatan Bumal Kabupaten Mamasa.

2.4 Subjek penelitian

Subjek penelitian adalah semua guru mata pelajaran biologi yang ada di SMP se Kecamatan Bumal Kabupaten Mamasa yang berjumlah lima (5) orang, maka penelitian ini merupakan penelitian populasi.

Tabel I

Daftar jumlah guru dan nama sekolah subjek penelitian

\begin{tabular}{llc}
\hline No & \multicolumn{1}{c}{ Nama Sekolah } & Jumlah Guru Biologi \\
\hline 1 & SMP Negeri 01 Buntumalangka & 1 orang \\
2 & SMP Swasta Puncak Sumua & 1 orang \\
3 & SMP Swasta Tallusikambik & 1 orang \\
4 & SMP Swasta Ranteberang & 1 orang \\
5 & SMP Negeri 3 Buntumalangka & 1 orang \\
& Jumlah & 5 orang \\
\hline
\end{tabular}

Sumber: olahan 2020

\subsection{Prosedur Penelitian}

Prosedur penelitian terdiri atas beberapa tahapan tahapan yaitu tahap persiapan, pelaksanaan, dan pengumpulan data :

\subsubsection{Tahap persiapan}

Pada tahan persiapan hal-hal yang akan dilakukan peneliti adalah :

a) Observasi pertama ke lokasi penelitian

b) Mengurus surat izin penelitian dari lembaga penelitian STKIP-PI Makassar untuk diteruskan ke lokasi penelitian.

c) Peneliti menghubungi kepala sekolah tempat mengadakan penelitian.

d) Peneliti menghubungi guru biologi SMP untuk menentukan jadwal penelitian.

2.5.2 Tahap pelaksanaan 
Pada tahap pelaksanaan hal-hal yang akan dilakukan peneliti adalah :

a) Peneliti menghubungi guru SMP yang bersangkutan dan menjelaskan masalah yang akan diteliti.

b) Peneliti memberikan pedoman angket kepada guru yang bersangkutan.

2.5.3 Tahap pengumpulan data

Pada tahap pengumpulan data, hal-hal yang dilakukan peneliti adalah data hasil angket guru biologi tentang hambatan yang dihadapi dalam menyusun silabus dan Rancangan Pelaksanaan Pembelajaran (RPP) kurikulum 2013 (K13) sebagai data hasil penelitian.

2.6 Instrumen Penelitian

Pada penelitian ini, instrument yang digunakan yaitu angket. Angket yang digunakan dalam penelitian ini disusun berdasarkan pada spesifikasi masalah yang diselidiki/ dikaji. Adapun jenis angket yang digunakan pada penelitian ini adalah angket tertutup yang intinya adalah meminta jawaban dari responden tentang hambatan-hambatan apa saja yang dihadapi oleh guru biologi dalam menyusun silabus dan Rancangan Pelaksanaan Pembelajaran (RPP) Kurikulum 2013 (K13) di SMP se Kecamatan Bumal Kabupaten Mamasa.

2.7 Teknik Analisis Data

Tahap selanjutnya Setelah data terkumpul adalah data diolah dengan menggunakan rumus untuk mengetahui faktor-faktor penghambat yang dihadapi oleh guru biologi dalam menyusun silabus dan Rancangan Pelaksanaan Pembelajaran (RPP) Kurikulum 2013 (K13) di SMP se Kecamatan Bumal Kabupaten Mamasa. Pengolahan data dilakukan dengan cara menghitung persentase per item, dan persentase per aspek yaitu sebagai berikut

2.7.1 Analisis per item

Analisis ini bertujuan untuk mengetahui alternatif yang paling menonjol dari setiap item. Adapun langkahlangkah yang dilakukan dalam menganalisis data setiap item adalah sebagai berikut:

a. Mengetahui jumlah responden yang mengisi angket.

b. Menjumlahkan pilihan yang sama dari seluruh responden pada satu item.

c. Menghitung persentase item dengan cara mencari rasio antara jumlah pilihan yang sama pada satu item dengan jumlah responden.

d. Dinyatakan dengan rumus sebagai berikut :

$$
\text { Persentase }=\frac{N}{P} x 100 \%
$$

(Nur, 2010)

Keterangan:

$N=$ jumlah pilihan yang sama pada satu item

$P=$ jumlah responden

2.7.2 Analisis per aspek

Analisis per aspek dilakukan untuk mengetahui totalitas faktor penghambat yang dihadapi oleh guru biologi dalam menyusun silabus dan Rancangan Pelaksanaan Pembelajaran (RPP) Kurikulum 2013 (K13) dan dinyatakan dengan rumus sebagai berikut:

Persentase $=\frac{N_{n}}{N x P} \times 100 \%$

(Nur, 2010)

Keterangan:

$N_{n}=$ jumlah pilihan yang sama dari item-item pada satu dimensi masalah

$N=$ jumlah item pada satu dimensi masalah

$P=$ jumlah responden 


\section{Hasil dan Pembahasan}

\subsection{Hasil Penelitian}

3.1.1 Prinsip-prinsip pengembangan silabus Kurikulum 2013 (K13)

Angket hasil penelitian tentang faktor penghambat penyusunan silabus dan RPP Kurikulum 2013 bagi guru biologi di SMP se Kecamatan Bumal Kabupaten Mamasa, yakni hambatan mengembangkan Silabus K13 berdasarkan prinsip pengembangan silabus K13, dapat dilihat pada Tabel 2 berikut.

Tabel II

Analisis persentase per item jawaban responden mengenai hambatan mengembangkan Silabus K13 berdasarkan prinsip pengembangan silabus $K 13$

\begin{tabular}{|c|c|c|c|c|}
\hline No & Item & Pilihan & $\mathbf{N}$ & $\%$ \\
\hline 1 & $\begin{array}{l}\text { Ilmiah artinya keseluruhan materi dan kegiatan yang } \\
\text { menjadi muatan dalam silabus harus benar dan dapat } \\
\text { dipertanggungjawabkan secara keilmuan. }\end{array}$ & Tidak & 5 & 100 \\
\hline 2 & $\begin{array}{l}\text { Relevan artinya cakupan, kedalaman, tingkat kesukaran dan } \\
\text { urutan penyajian materi dalam silabus harus disesuaikan } \\
\text { dengan tingkat perkembangan fisik, intelektual, sosial, } \\
\text { emosional dan spiritual peserta didik. }\end{array}$ & Tidak & 1 & 80 \\
\hline 3 & $\begin{array}{l}\text { Sistematis artinya komponen-komponen silabus saling } \\
\text { berhubungan secara fungsional dalam mencapai } \\
\text { kompetensi. }\end{array}$ & $\begin{array}{c}\text { Ya } \\
\text { Tidak }\end{array}$ & 5 & 100 \\
\hline 4 & $\begin{array}{l}\text { Konsisten artinya adanya hubungan yang konsisten (ajeg, taat } \\
\text { asas) antara kompetensi dasar, indikator, materi } \\
\text { pembelajaran, kegiatan pembelajaran, teknik, sumber belajar, } \\
\text { dan instrumen penilaian. }\end{array}$ & Tidak & 1 & 80 \\
\hline 5 & $\begin{array}{l}\text { Memadai artinya cakupan indikator, materi pembelajaran, } \\
\text { kegiatan pembelajaran, sumber belajar, dan sistem } \\
\text { penilaian cukup untuk menunjang pencapaian kompetensi } \\
\text { dasar. }\end{array}$ & Tidak & 2 & 40 \\
\hline 6 & $\begin{array}{l}\text { Aktual dan Kontekstual artinya cakupan indikator, materi } \\
\text { pembelajaran, kegiatan pembelajaran, sumber belajar, dan } \\
\text { sistem penilaian memperhatikan perkembangan ilmu, } \\
\text { teknologi, dan seni mutakhir dalam kehidupan nyata, serta } \\
\text { peristiwa yang terjadi. }\end{array}$ & Tidak & 4 & 20 \\
\hline 7 & $\begin{array}{l}\text { Fleksibel artinya keseluruhan komponen silabus dapat } \\
\text { mengakomodasi keragaman peserta didik, pendidik, serta } \\
\text { dinamika perubahan yang terjadi di sekolah dan kebutuhan } \\
\text { masyarakat. }\end{array}$ & Tidak & 3 & 40 \\
\hline 8 & 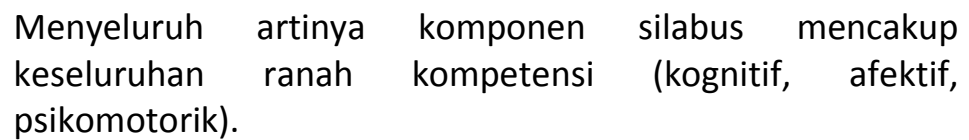 & Tidak & 3 & 60 \\
\hline
\end{tabular}

3.1.2 Langkah-langkah pengembangan Silabus Kurikulum 2013 (K13)

Angket hasil penelitian tentang faktor penghambat penyusunan silabus dan RPP Kurikulum 2013 bagi guru biologi di SMP se Kecamatan Bumal Kabupaten Mamasa, yakni hambatan mengembangkan Silabus K13 berdasarkan prinsip pengembangan silabus K13, dapat dilihat pada Tabel 3 berikut. 
Tabel III

Analisis persentase per item jawaban responden mengenai hambatan mengembangkan Silabus K13 berdasarkan langkah-langkah pengembangan silabus K13

\begin{tabular}{cc}
\hline No & Item \\
\hline 1 & Mengkaji Kompetensi Inti (KI) dan Kompetensi Dasar (KD) adalah \\
& mengkaji dasar mata pelajaran sebagaimana tercantum pada standa \\
& Isi, dengan memperhatikan hal-hal berikut ; (i) Urutan berdasarkan \\
& hierarki konsep disiplin ilmu dan atau tingkat kesulitan materi, tidak \\
& harus selalu sesuai dengan urutan yang ada di SI. (ii) Keterkaitan \\
& antara Kompetensi Inti dan Kompetensi Dasar dalam mata pelajaran.
\end{tabular}

2 Merumuskan indikator. Indikator merupakan penanda pencapaian Kompetensi Dasar yang ditandai oleh perubahan perilaku yang dapat diukur mencakup sikap, pengetahuan, dan keterampilan. Indikator dikembangkan sesuai dengan karakteristik peserta didik, mata pelajaran, satuan pendidikan, potensi daerah dan dirumuskan dalam kata kerja operasional yang terukur dan dapat diobservasi.

3 Mengidentifikasi materi pokok/pembelajaran yaitu materi harus menunjang pencapaian kompetensi dasar dengan mempertimbangkan ; (i) Potensi peserta didik. (ii) Relevansi dengan karakteristik daerah. (iii) Tingkat perkembangan fisik, intelektual, emosional, sosial, dan spritual peserta didik. (iv) Kebermanfaatan bagi peserta didik. (v) Struktur keilmuan. (vi) Aktualitas, kedalaman, keluasan materi pembelajaran. (vii) Relevansi dengan kebutuhan peserta didik dan tuntutan lingkungan. (viii) Adanya alokasi waktu.

4 Mengembangkan kegiatan pembelajaran. Pengembangan dalam hal ini yaitu, kegiatan pembelajaran dirancang untuk memberikan pengalaman belajar yang melibatkan proses mental dan fisik melalui interaksi antar peserta didik, peserta didik dengan guru, lingkungan, dan sumber belajar lainnya dalam rangka pencapaian kompetensi dasar. Pengalaman belajar dapat terwujud melalui penggunaan pendekatan pembelajaran yang bervariasi dan berpusat pada peserta didik.

5 Penentuan jenis penilaian. Penilaian pencapaian kompetensi dasar peserta didik dilakukan berdasarkan indikator. Penilaian dilakukan dengan menggunakan tes dan non tes dalam bentuk tertulis maupun lisan, pengamatan kinerja, pengukuran sikap, penilaian hasil karya berupa tugas, proyek dan produk, penggunaan portofolio, dan penilaian diri. Penilaian merupakan serangkaian kegiatan untuk memperoleh, menganalisis, dan menafsirkan data tentang proses dan hasil belajar peserta didik.

6 Menentukan alokasi waktu. Penentuan alokasi waktu pada setiap kompetensi dasar didasarkan pada jumlah minggu efektif dan alokasi waktu mata pelajaran perminggu dengan mempertimbangkan jumlah kompetensi dasar, keluasan, kedalaman, tingkat kesulitan, dan tingkat kepentingan kompetensi dasar. Alokasi waktu yang dicantumkan

\begin{tabular}{ccc} 
Pilihan & $\mathbf{N}$ & $\%$ \\
\hline Ya & 1 & 20
\end{tabular}

Tidak $\quad 4 \quad 80$

Ya $\quad 1 \quad 20$

Tidak $\quad 4 \quad 80$

Ya 240

Tidak 360

Ya $\quad 1 \quad 20$

Tidak $\quad 4 \quad 80$

Ya $\quad 1 \quad 20$

Tidak $\quad 4 \quad 80$

Ya $\quad 2 \quad 40$

Tidak $\quad 3 \quad 60$ dalam silabus merupakan perkiraan waktu untuk menguasai kompetensi dasar yang dibutuhkan oleh peserta didik yang beragam.

7 Menentukan sumber belajar. Sumber belajar adalah rujukan, objek atau bahan yang digunakan untuk kegiatan pembelajaran, yang berupa media cetak dan elektronik, nara sumber, serta lingkungan

Ya $\quad 4 \quad 80$


fisik, alam, sosial, serta budaya. Penentuan sumber belajar

didasarkan pada standar kompetensi dan kompetensi dasar serta

materi pembelajaran, kegiatan pembelajaran, dan indikator

pencapaian kompetensi.

Sumber: Diolah, 2020

\subsubsection{Komponen penyusunan RPP Kurikulum 2013 (K13)}

Angket hasil penelitian tentang faktor penghambat penyusunan silabus dan RPP Kurikulum 2013 bagi guru biologi di SMP se Kecamatan Bumal Kabupaten Mamasa, yakni hambatan mengembangkan Silabus K13 berdasarkan Komponen penyusunan RPP K13, dapat dilihat pada Tabel 4 berikut.

Tabel 4.

Analisis persentase per item jawaban responden mengenai hambatan dalam menyusun RPP K13 berdasarkan Komponen penyusunan RPP K13

\begin{tabular}{|c|c|c|c|c|}
\hline No & Item & Pilihan & $\mathbf{N}$ & $(\%)$ \\
\hline \multirow[t]{2}{*}{1} & \multirow{2}{*}{$\begin{array}{l}\text { Identitas mata pelajaran, meliputi ; Nama sekolah, Mata Pelajaran, } \\
\text { Kelas/Semester, Materi Pokok, Alokasi Waktu. }\end{array}$} & Ya & - & - \\
\hline & & Tidak & 5 & 100 \\
\hline \multirow[t]{2}{*}{2} & \multirow{2}{*}{$\begin{array}{l}\text { Kompetensi Inti, merupakan tingkat kemampuan untuk mencapai } \\
\text { standar kompetensi lulusan yang harus dimiliki oleh peserta didik } \\
\text { pada setiap tingkat, kelas atau program. }\end{array}$} & Ya & - & \\
\hline & & Tidak & 5 & 100 \\
\hline \multirow[t]{2}{*}{3} & \multirow{2}{*}{$\begin{array}{l}\text { Kompetensi dasar, adalah sejumlah kemampuan yang harus dikuasai } \\
\text { peserta didik dalam mata pelajaran tertentu sebagai rujukan } \\
\text { penyusunan indikator kompetensi dalam suatu pelajaran. }\end{array}$} & Ya & 1 & 20 \\
\hline & & Tidak & 4 & 80 \\
\hline \multirow[t]{3}{*}{4} & $\begin{array}{l}\text { Indikator pencapaian kompetensi, adalah perilaku yang dapat diukur } \\
\text { dan/atau diobservasi untuk menunjukkan ketercapaian kompetensi }\end{array}$ & Ya & - & - \\
\hline & $\begin{array}{l}\text { dasar tertentu yang menjadi acuan penilaian mata pelajaran. } \\
\text { Indikator pencapaian kompetensi dirumuskan dengan menggunakan }\end{array}$ & Tidak & 5 & 100 \\
\hline & $\begin{array}{l}\text { kata kerja operasional yang dapat diamati dan diukur, yang } \\
\text { mencakup pengetahuan, sikap, dan keterampilan. }\end{array}$ & & & \\
\hline \multirow[t]{2}{*}{5} & Tujuan pembelajaran, menggambarkan proses dan hasil belajar yang & Ya & 1 & 20 \\
\hline & dasar. & Tidak & 4 & 80 \\
\hline \multirow[t]{2}{*}{6} & \multirow{2}{*}{$\begin{array}{l}\text { Materi ajar, yaitu memuat fakta, konsep, prinsip, dan prosedur yang } \\
\text { relevan, serta ditulis dalam bentuk butir-butir sesuai dengan } \\
\text { rumusan indikator pencapaian kompetensi. }\end{array}$} & Ya & 1 & 20 \\
\hline & & Tidak & 4 & 80 \\
\hline \multirow[t]{2}{*}{7} & $\begin{array}{l}\text { Metode pembelajaran, digunakan oleh guru untuk mewujudkan } \\
\text { suasana belajar dan proses pembelajaran agar peserta didik } \\
\text { mencapai kompetensi dasar atau seperangkat indikator yang telah }\end{array}$ & Ya & 2 & 40 \\
\hline & $\begin{array}{l}\text { ditetapkan. Pemilihan metode pembelajaran disesuaikan dengan } \\
\text { situasi dan kondisi peserta didik, serta karakteristik dari setiap } \\
\text { indikator dan kompetensi yang hendak dicapai pada setiap mata } \\
\text { pelajaran. }\end{array}$ & Tidak & 3 & 60 \\
\hline \multirow[t]{2}{*}{8} & $\begin{array}{l}\text { Media, alat, dan sumber pembelajaran. Media belajar adalah segala } \\
\text { sesuatu yang dapat menyalurkan pesan untuk mendorong } \\
\text { terciptanya proses belajar, contohnya laptop, komputer, gambar, dan }\end{array}$ & Ya & 5 & 100 \\
\hline & $\begin{array}{l}\text { sebagainya. Alat peraga merupakan segala sesuatu alat yang dapat } \\
\text { menunjang keefektifan dan pemahaman informasi pembelajaran, } \\
\text { contohnya torso atau patung sebagai alat peraga. Dan sumber belajar } \\
\text { adalah semua sumber yang dapat digunakan peserta didik dalam } \\
\text { belajar, contohnya buku paket. }\end{array}$ & Tidak & - & - \\
\hline 9 & Kegiatan pendahuluan, merupakan kegiatan awal dalam suatu & $\mathrm{Ya}$ & 1 & 20 \\
\hline
\end{tabular}


pertemuan pembelajaran yang ditujukan untuk membangkitkan motivasi dan memfokuskan perhatian peserta didik untuk Tidak $4 \quad 80$ berpartisipasi aktif dalam proses pembelajaran.

10 Kegiatan inti, merupakan proses pembelajaran untuk mencapai KD. Kegiatan pembelajaran dilakukan secara interaktif, inspiratif, menyenangkan, menantang, memotivasi peserta didik untuk berpartisipasi aktif, dan memberikan ruang yang cukup bagi prakarsa, kreativitas, dan kemandirian sesuai dengan bakat, minat, serta perkembangan fisik dan psikologis peserta didik. Kegiatan ini dilakukan secara sistematis dan sistemik melalui proses eksplorasi, elaborasi, dan konfirmasi.

11 Kegiatan penutup, merupakan kegiatan yang dilakukan untuk mengakhiri aktivitas pembelajaran yang dapat dilakukan dalam bentuk rangkuman atau simpulan, penilaian dan refleksi, umpan balik, serta tindaklanjut.

12 Penilaian hasil belajar, merupakan sebuah prosedur dan instrumen penilaian proses dan hasil belajar yang disesuaikan dengan indikator pencapaian kompetensi dan mengacu kepada standar penilaian.

Sumber: Diolah, 2020

Tidak $\quad 3 \quad 60$

$\begin{array}{lll}Y a & 1 & 20\end{array}$

Tidak $\quad 4 \quad 80$

Ya

Tidak $\quad 5 \quad 100$

3.1.4 Hasil analisis persentase setiap aspek

Angket yang telah diisi oleh guru mengenai faktor penghambat penyusunan Silabus dan RPP Kurikulum 2013 bagi guru biologi di SMP Se Kecamatan Bumal Kabupaten Mamasa, dapat dilihat pada tabel 5 berikut.

Tabel 5

Analisis persentase per aspek jawaban responden mengenai faktor penghambat penyusunan Silabus dan RPP Kurikulum 2013 bagi guru biologi di SMP Se Kecamatan Bumal Kabupaten Mamasa

\begin{tabular}{lcccr}
\multicolumn{1}{c}{ Aspek } & $\begin{array}{c}\text { Jumlah } \\
\text { ítem }\end{array}$ & Pilihan & N & $\begin{array}{c}\text { Presentase } \\
\text { (\%) }\end{array}$ \\
\hline Prinsip-prinsip pengembangan silabus K13 & 8 & Ya & 13 & $32,5 \%$ \\
& & Tidak & 27 & $67,5 \%$ \\
Langkah-langkah pengembangan silabus & 7 & Ya & 12 & $34 \%$ \\
K13 & & Tidak & 23 & $65 \%$ \\
Komponen penyusunan RPP Kurikulum & 12 & Ya & 14 & $23 \%$ \\
2013 (K13) & & Tidak & 46 & $76 \%$ \\
\hline
\end{tabular}

Sumber: Diolah, 2020

\section{Pembahasan}

Silabus dan RPP adalah perangkat pembelajaran yang harus disiapkan oleh guru sebelum melaksanakan pembelajaran. Menurut Permendikbud No 65 tahun 2013, RPP dikembangkan dari silabus untuk mengarahkan kegiatan pembelajaran peserta didik dalam upaya mencapai Kompetensi Dasar (KD). Setiap pendidik pada satuan pendidikan berkewajiban menyusun RPP secara lengkap dan sistematis. Perangkat pembelajaran ini harus disusun dengan baik agar pembelajaran dapat berlangsung sebagaimana mestinya. Kurikulum 2013 yang diterapkan di sekolah-sekolah saat ini dipengaruhi oleh bagaimana guru menyusun dan menerapkan Silabus dan RPP K13 untuk bahan mengajarnya. Jika tidak dibuat dengan baik maka 
pembelajaran tidak akan berjalan maksimal. Hal inilah yang menjadi salah satu hambatan pelaksanaan Kurikulum K13 di sekolah yang sering terjadi.

Dari penelitian yang telah dilakukan, diperoleh hasil yang menunjukkan adanya faktor penghambat yang dihadapi guru biologi dalam menyusun silabus dan Rancangan Pelaksanaan Pembelajaran (RPP) Kurikulum 2013 (K13) di SMP se Kecamatan Bumal Kambupaten Mamasa. Pernyataan ini didukung dengan adanya hasil analisis data secara deskriptif yang dapat dilihat pada tabel 5 yang berisi analisis persentase per aspek jawaban responden mengenai faktor penghambat penyusunan Silabus dan RPP Kurikulum 2013 bagi guru biologi di SMP Se Kecamatan Bumal Kabupaten Mamasa, dengan hasil sebagai berikut:

\subsection{Prinsip-prinsip pengembangan silabus K13}

Dari hasil angket yang telah diisi guru tentang mengembangkan silabus K13 berdasarkan prinsip-prinsip pengembangan silabus, dapat dilihat dari Tabel 4.4 pada kolom pertama bahwa 32,5\% guru biologi dalam menyusun silabus K13 di SMP se Kecamatan Bumal Kabupaten Mamasa mengalami hambatan, dan 67,5\% guru biologi dalam menyusun silabus K13 di SMP se Kecamatan Bumal Kabupaten Mamasa tidak mengalami hambatan. Adapun jenis-jenis hambatan yang dihadapi guru biologi antara lain: guru belum menguasai tentang Kurikulum 2013 karena pelatihan K13 bagi tenaga pengajar di desa-desa masih kurang, kurangnya kemampuan dasar yang dimiliki siswa, kemampuan daya serap siswa yang berbeda-beda, penyaluran silabus K13 secara online tidak dapat di download di desa-desa karena jaringan internet tidak ada sehingga guru harus ke luar desa mencari jaringan untuk akses silabus K13, beberapa sekolah belum memiliki laboratorium, sumber belajar berupa buku-buku pegangan sangat terbatas.

\subsection{Langkah-langkah pengembangan silabus K13}

Hasil angket yang telah diisi guru tentang mengembangkan silabus K13 berdasarkan langkah-langkah pengembangan silabus K13, yang dilihat pada tabel 5 di kolom kedua menunjukkan bahwa 34 \% guru biologi dalam mengembangkan silabus K13 di SMP se Kecamatan Bumal Kabupaten Mamasa mengalami hambatan, dan 65 \% guru biologi dalam menyusun silabus K13 di SMP se Kecamatan Bumal Kabupaten Mamasa tidak mengalami hambatan. Adapun jenis-jenis hambatan yang dihadapi guru biologi antara lain: potensi dan tingkat perkembangan peserta didik yang masih kurang bahkan guru kadang harus mengajar dengan menggunakan bahasa daerah karena kemampuan intelektual siswa yang masih rendah, guru kesulitan dalam hal penilaian terutama dalam penilaian sikap karena penilaian dalam kurikulum 2013 memiliki indikator yang banyak dan harus dinilai secara terus menerus dan berkesinambungan sedangkan sikap/tingkah laku siswa berbeda-beda setiap harinya, penentuan jenis penilaian hanya dapat dilakukan dalam bentuk lisan dan tertulis sedangkan penilaian dalam bentuk praktek tidak dapat dilakukan karena berbagai sarana pendukung sangat terbatas dan ruangan laboratorium yang belum ada, alokasi waktu yang telah dirancang sering mengalami perubahan seperti adanya libur secara tiba-tiba jika ada acara pernikahan ataupun kematian atau bahkan libur saat musim panen, sekolah sangat kekurangan sumber belajar yang berupa alat-alat peraga, media cetak dan media elektronik.

\subsection{Komponen penyusunan RPP Kurikulum 2013 (K13)}

Dari hasil angket yang telah diisi guru tentang penyusunan RPP K13 berdasarkan Komponen penyusunan RPP Kurikulum 2013 (K13), dapat dilihat dari Tabel 4.4 pada kolom ketiga bahwa $23 \%$ guru biologi dalam penyusunan RPP K13 di SMP se Kecamatan Bumal Kabupaten Mamasa mengalami hambatan, dan $76 \%$ guru biologi dalam penyusunan RPP K13 di SMP se Kecamatan Bumal Kabupaten Mamasa tidak mengalami hambatan. Adapun jenis-jenis hambatan yang dihadapi guru biologi antara lain: letak sekolah yang berada di desa-desa terpencil sehingga media, alat, dan sumber pembelajaran seperti laptop, komputer, dan torso serta buku paket masih sangat kurang, guru sulit menghidupkan suasana belajar peserta didik dengan penerapan berbagai metode pembelajaran karena kondisi ruang kelas yang sempit dan hanya dibatasi oleh sekat papan sehingga jika menggunakan metode diskusi atau permainan dapat mengganggu kelas lain, belum tersedianya ruangan laboratorium biologi untuk kegiatan praktikum, kurangnya tingkat pengetahuan 
dasar siswa serta daya serap yang berbeda-beda membuat peserta didik kurang aktif dalam proses pembelajaran, kurangnya umpan balik siswa terhadap guru saat guru menyampaikan materi.

Dari hasil analisis deskriptif di atas, menunjukkan bahwa setiap aspek dalam penyusunan Silabus dan Rancangan Pelaksanaan Pembelajaran (RPP) Kurikulum 2013 (K13) oleh guru biologi di SMP se Kecamatan Bumal Kabupaten Mamasa mengalami beberapa faktor penghambat. Jumlah hasil persentase faktor penghambat ini lebih sedikit jika dibandingkan dengan jumlah hasil persentase tidak adanya faktor penghambat yang dihadapi guru biologi dalam menyusun silabus dan RPP K13. Namun, berdasarkan hasil penelitian langsung yang telah dilakukan dan hasil wawancara kepada guru di sekolah-sekolah ditemukan banyak faktor penghambat yang dihadapi guru biologi di SMP se Kecamatan Bumal Kabupaten Mamasa dalam menyusun silabus dan Rancangan Pelaksanaan Pembelajaran (RPP) Kurikulum 2013 (k13), karena (i) sekolah terletak di desa terpencil sehingga sumber-sumber belajar sangat terbatas, (ii) sekolah kekurangan buku-buku pelajaran berbasis K13 sehingga beberapa sekolah masih menggunakan buku KTSP, (iii) media dan alat di sekolah sangat kurang, (iv) sekolah masih kekurangan fasilitas penunjang pembelajaran lainnya seperti ruangan laboratorium biologi, (v) Komputer, listrik, dan jaringan yang belum ada membuat guru sulit untuk mengakses silabus dan RPP K13 yang dapat di download secara online, (vi) tenaga pengajar di sekolah masih perlu pelatihan kurikulum 2013 karena masih dianggap baru.

Karena itu, untuk menuntaskan implementasi kurikulum 2013, pemerintah terus berkewajiban mengawal implementasi kurikulum secara tuntas, melanjutkan penulisan, pengadaan dan pendistribusian buku, dengan dukungan pemerintah daerah dan masyarakat di samping melakukan pengawasan terhadap pelaksanaan kurikulum 2013 di lapangan dan selalu terbuka terhadap feedback dari semua kalangan (Huriah, 2017)

\section{Kesimpulan}

Terdapat beberapa faktor penghambat yang dihadapi guru biologi dalam menyusun silabus dan RPP Kurikulum 2013 di SMP se Kecamatan Bumal Kabupaten Mamasa, dengan hambatan antara lain: kurangnya pelatihan Kurikulum 2013 bagi tenaga pengajar di daerah terpencil membuat guru kesulitan menyusun dan mengembangkan silabus dan RPP K13, guru di sekolah sangat kekurangan fasilitas penunjang pembelajaran seperti buku-buku paket berbasis K13, guru kekurangan alat-alat untuk praktek seperti torso dan fasilitas laboratorium biologi, di sekolah tidak ada komputer, dan listrik, guru tidak dapat mengakses silabus dan RPP secara online karena di desa belum ada jaringan internet, kemampuan dasar yang dimiliki siswa masih terbatas, keadaan sekolah dan tenaga pengajar serta peserta didik yang serba kekurangan ini membuat guru menghadapi kendala dalam penyusunan dan pengembangan silabus dan RPP K13 di SMP se Kecamatan Bumal Kabupaten Mamasa.

\section{Referensi}

Asmarani, Vinika., 2018, Identifikasi Hambatan Pembelajaran Biologi Dalam Pelaksanaan Kurikulum 2013 Bagi Pendidik Biologi SMA Negeri Se kota Madya Bandar Lampung, Skripsi, Fakultas Keguruan Dan Ilmu Pendidikan Universitas Lampung, Bandar Lampung.

Chandrawati, Neli., 2013, Struktur Kurikulum kurikulum 2013, http://nelly-chandrawati/2013/03/strukturkurikulum-kurikulum-2013-sd.html, diakses tanggal 27 April 2019.

Fitrianingsih, Eka., 2018, Hambatan Guru IPA Kelas VII Dalam Mengimplementasikan Kurikulum 2013 Revisi Se kota Madya Bandar Lampung Tahun Pelajaran 2016/2017, Skripsi, Fakultas Keguruan Dan IImu Pendidikan Universitas Lampung, Bandar Lampung.

Hardianti, Sitti., 2017, Implementasi Kurikulum 2013 Pada Proses Pembelajaran Guru Mata Pelajaran Fisika Tingkat SMA Negeri Di Kabupaten Bone, Skripsi, Fakultas Tarbiyah Dan Keguruan UIN Alauddin, Makassar. 
Huriah, 2017., Faktor-faktor Penghambat Penerapan Kurikulum 2013 Di MA Al-Inthishor Desa Bendega Tanjung Karang Kecamatan Sekarbela Tahun Pelajaran 2016/2017, Skripsi, Fakultas Ilmu Tarbiyah Dan Keguruan (FITK) Universitas Islam Negeri (UIN), Mataram.

Niron, Maria., 2009, Modul Pengembangan Silabus dan Rencana Pelaksanaan Pembelajaran dalam KTSP, Universitas Negeri Yogyakarta, diakses tanggal 30 Oktober 2019.

Nur, Surahman., 2010, Studi Tentang Faktor-faktor Penghambat yang Dihadapi Guru Biologi Dalam Menyusun Rancangan Pelaksanaan Pembelajaran Kurikulum Tingkat Satuan Pendidikan di SMP Se Kecamatan Bastem Kabupaten Luwu, skripsi, Jurusan Pendidikan Biologi Fakultas Matematika dan Ilmu Pengetahuan Alam UNM, Makassar.

Prasetya, Ivan., 2015, Hambatan-hambatan Pelaksanaan Kurikulum 2013 Di SMK Negeri 1 Sayegan Yogyakarta. Skripsi, Program Studi Pendidikan Teknik Otomotif Fakultas Teknik Universitas Negeri, Yogyakarta.

Peraturan Menteri Pendidikan Nasional Nomor. 65 tahun 2013. Standar Proses. Jakarta: Kementrian Pendidikan dan Kebudayaan.

Peraturan Menteri Pendidikan Nomor 103 Tahun (2014). Pembelajaran Pada Pendidikan Dasar Dan Pendidikan Menengah. Jakarta: Kementrian Pendidikan dan Kebudayaan.

Undang-Undang Nomor 20 tahun 2003. Sistem Pendidikan Nasional. Jakarta: Pendidikan dan Kebudayaan 